\title{
Article \\ Effects of Different Soils on the Biomass and Photosynthesis of Rumex nepalensis in Subalpine Region of Southwestern China
}

\author{
Heliang He ${ }^{1,2,3}$, Lan $\mathrm{Yu}^{1,4}$, Xiaocheng Yang ${ }^{4}$, Lin Luo ${ }^{1,3}$, Jia Liu ${ }^{1}$, Jing Chen ${ }^{1,4}$, Yongping Kou ${ }^{1}$, \\ Wenqiang Zhao ${ }^{1}$ and Qing Liu ${ }^{1, *}$ \\ 1 Chengdu Institute of Biology, Chinese Academy of Sciences, Chengdu 610041, China; \\ heheliang@cib.ac.cn (H.H.); yulanhhl@126.com (L.Y.); luolin@cib.ac.cn (L.L.); liujia@cib.ac.cn (J.L.); \\ chenjing1@stu.cdut.edu.cn (J.C.); kouyp@cib.ac.cn (Y.K.); zhaowq@cib.ac.cn (W.Z.) \\ 2 College of Agriculture, Forestry and Food Engineering, Yibin University, Yibin 644007, China \\ 3 University of Chinese Academy of Sciences, Beijing 100049, China \\ 4 College of Ecology and Environment, Chengdu University of Technology, Chengdu 610059, China; \\ yxc39@163.com \\ * Correspondence: liuqing@cib.ac.cn
}

check for updates

Citation: He, H.; Yu, L.; Yang, X.; Luo, L.; Liu, J.; Chen, J.; Kou, Y.; Zhao, W.; Liu, Q. Effects of Different Soils on the Biomass and Photosynthesis of Rumex nepalensis in Subalpine Region of Southwestern China. Forests 2022, 13, 73. https:// doi.org/10.3390/f13010073

Academic Editors: Zuoqiang Yuan, Guigang Lin and Cristina Aponte

Received: 14 December 2021 Accepted: 28 December 2021

Published: 5 January 2022

Publisher's Note: MDPI stays neutral with regard to jurisdictional claims in published maps and institutional affiliations.

Copyright: (c) 2022 by the authors. Licensee MDPI, Basel, Switzerland. This article is an open access article distributed under the terms and conditions of the Creative Commons Attribution (CC BY) license (https:/ / creativecommons.org/licenses/by/ $4.0 /)$.

\begin{abstract}
The performance of Rumex nepalensis, an important medicinal herb, varies significantly among subalpine grasslands, shrublands and forest ecosystems in southwestern China. Plantsoil feedback is receiving increasing interest as an important driver influencing plant growth and population dynamics. However, the feedback effects of soils from different ecosystems on R. nepalensis remain poorly understood. A greenhouse experiment was carried out to identify the effects of different soil sources on the photosynthesis and biomass of $R$. nepalensis. R. nepalensis was grown in soils collected from the rooting zones of $R$. nepalensis (a grassland soil, RS treatment), Hippophae rhamnoides (a shrub soil, HS treatment), and Picea asperata (a forest soil, PS treatment). The chlorophyll contents, net photosynthetic rates, and biomasses of $R$. nepalensis differed significantly among the three soils and followed the order of RS > HS > PS. After soil sterilization, these plant parameters followed the order of RS > PS > HS. The total biomass was 16.5 times higher in sterilized PS than in unsterilized PS, indicating that the existence of soil microbes in P. asperata forest ecosystems could strongly inhibit $R$. nepalensis growth. The root to shoot biomass ratio of $R$. nepalensis was the highest in the sterilized PS but the lowest in the unsterilized PS, which showed that soil microbes in PS could change the biomass allocation. Constrained redundancy analysis and path analysis suggested that soil microbes could impact the growth of $R$. nepalensis via the activities of soil extracellular enzymes (e.g., $\beta-1,4-\mathrm{N}$-acetylglucosaminidase (NAG)) in live soils. The soil total soluble nitrogen concentration might be the main soil factor regulating $R$. nepalensis performance in sterilized soils. Our findings underline the importance of the soil microbes and nitrogen to $R$. nepalensis performance in natural ecosystems and will help to better predict plant population dynamics.
\end{abstract}

Keywords: soil microbes; extracellular enzymes; biomass allocation; net photosynthetic rate; plant growth; soil nitrogen concentration

\section{Introduction}

In terrestrial ecosystems, plants can modify soil properties that consequently influence the performance of other conspecific or heterospecific plants; this mechanism is known as "plant-soil feedback" (PSF) [1,2]. PSF can affect plant population dynamics and species coexistence [3-7]. In previous studies, many ecological theories and empirical studies have indicated that plant interspecific competition for resources (e.g., moisture, light and nutrients) [8,9] and polluted environments (e.g., heavy metal contamination) [10-12] could influence plant biochemical characteristics, individual plant fitness and community assembly. However, the feedback effects of different soils on plant fitness have received relatively little attention [7]. Different plant species can coexist in a local area, and their 
presence may be determined by different soil microbes and nutrients [13-15]. Therefore, determining the feedback effects of different soil microbes and nutrient properties on plant performance is necessary to understand the interactions between individual plants and to predict plant coexistence, population establishment and persistence $[4,16]$.

Soil nutrients and soil microbes are two main factors that affect plant production, diversity and population development $[17,18]$. The microbes are ubiquitous in soils of all plant communities and exert profound effects on plant performance directly through mutualistic or pathogenic interactions $[19,20]$ and indirectly by participating in nutrient cycling [21]. Soil nitrogen and phosphorus cycles are catalyzed mostly by the activities of soil extracellular enzymes, which are synthesized mainly by soil microbes [22]. Soil nutrient conditions are governed primarily by soil microbes that may decompose complex organic matter and release mineral elements by secreting extracellular enzymes $[23,24]$. Consequently, soil microbes and nutrients interact to influence plant performance and population dynamics [25].

Plant physiological and biochemical characteristics, especially their photosynthetic capacities and pigment concentrations, can represent plant fitness and survival and reflect plant responses to different soil conditions [26-29]. For example, a high photosynthetic capacity is conducive to high plant growth rates and biomass accumulation in suitable natural environments [26]. Photosynthetic pigments, including chlorophyll a (Chl a), chlorophyll $\mathrm{b}(\mathrm{Chl} \mathrm{b})$ and carotenoids, are essential factors in plant photosynthesis and can be used to monitor photosynthetic events and evaluate the physiological status of plants [30]. Chl a and $\mathrm{Chl} \mathrm{b}$ are the major light-harvesting photosynthetic pigments in the chloroplast and are of great significance to the photosynthetic physiology and stress physiology of plants [31]. High leaf chlorophyll contents and photosynthetic rates represent plant adaptability in the highly competitive production environment because these characteristics promote plant rapid growth and enable plants to quickly occupy the limited space and resources [32]. Soil microbes and nutrients can influence plant photosynthetic performance, growth rates and yield [33-35]. At present, studies on PSF focus mainly on the accumulation of plant biomass [2,36,37]. However, little is known about how PSF affects plant performance from the perspective of plant physiological characteristics.

The subalpine region of southwestern China is considered to be a hot spot of biodiversity, where natural ecosystems were damaged by deforestation due to the increased demand of the timber market for materials during the last century [38]. In an effort to revive and restore the forest landscapes in this zone, China conducted reforestation projects in the 1950s and subsequently launched the Natural Forest Protection Program (NFPP) in 2000. Therefore, many different grass, shrub and tree patches were formed within relatively short distances (scales of hundreds to thousands of meters) in this area. Rumex nepalensis is a perennial herb with large roots, erect stems and a height of $50-100 \mathrm{~cm}$. It is widely distributed throughout the subalpine region of southwestern China and is well known to be an important medicinal herb [39]. R. nepalensis is dominant in some grasslands and coexists with Hippophae rhamnoides in shrublands, whereas it cannot grow in the understory of mature Picea asperata forests. This phenomenon is generally believed to result from plant interspecific competition for resources (e.g., moisture, light and nutrients) [8,9], but the feedback effects of the different soil parameters on $R$. nepalensis growth in these ecosystems remain unclear.

To enhance our understanding of the distinct performances of $R$. nepalensis in subalpine ecosystems from the perspective of PSF, we conducted a pot culture experiment with rooting zone soils collected from three dominant plant species located in different ecosystems and corresponding sterilized soils. The effects of different soils on the photosynthesis, biomass, and biomass allocation of $R$. nepalensis were investigated. We tested the hypotheses that (1) R. nepalensis photosynthesis, biomass and biomass allocation would differ significantly among soils characterized by different PSF effects and (2) the soil microbes of the P. asperata 
rooting zone would inhibit the growth of $R$. nepalensis, as indicated by the absence of $R$. nepalensis in the understory of mature P. asperata forests.

\section{Materials and Methods}

\subsection{Soil and Seed Collection}

In October 2018, based on a previous field investigation, we selected three different lifeform plant species ( $R$. nepalensis, a perennial herb; H. rhamnoides, a widespread shrub; and P. asperata, a dominant tree) from grasslands, shrublands and forest ecosystems, respectively, in the subalpine region of southwestern China $\left(31^{\circ} 37^{\prime}-47^{\prime} \mathrm{N}, 102^{\circ} 41^{\prime}-50^{\prime} \mathrm{E}\right.$, and $2966-3234$ $\mathrm{m}$ a.s.1.), for soil collection. These species are widely distributed and easily found in the study area. The soil samples (0-20 cm depth) were collected from the rooting zones $(<0.2 \mathrm{~m}$ from the base of the stem of $R$. nepalensis; $<0.5 \mathrm{~m}$ from the base of the stem of $H$. rhamnoides; and $<1 \mathrm{~m}$ from the base of the stem of P. asperata) of 20-30 mature individual plants of each species. The samples were transported back to the lab and pooled. Large rocks and roots were removed from the soils, and the soils were sieved using a $5 \mathrm{~mm}$ mesh, packaged in separate polypropylene woven bags and stored in a cool $\left(<17^{\circ} \mathrm{C}\right)$, dark room. Seeds of $R$. nepalensis were collected from a population near the fields where the soils were collected.

\subsection{Greenhouse Experiment}

The greenhouse pot experiment was conducted in a laboratory at Chengdu Institute of Biology, Chinese Academy of Sciences. To ensure good soil aeration and drainage, we added $30 \%$ quartz sand ( $w / w$, sterilized by autoclaving at $121{ }^{\circ} \mathrm{C}$ for $30 \mathrm{~min}$ ) to all soils based on the ratio of stones to soil after sieving. The field-collected soils of each soil origin (i.e., from beneath each plant species) were homogenized separately. The soil samples were divided into two parts: one was used directly in the subsequent pot experiments, and the other was sterilized by triple-steam pasteurization at $80^{\circ} \mathrm{C}$ for two hours every two days for six days [37]. This sterilization approach can have fewer side effects on soil chemical and physical properties than other sterilization methods [40], and the key chemical properties of our soils were broadly unaffected (Table 1 ). The $R$. nepalensis seeds were surface-sterilized with a $0.5 \%(w / v)$ potassium permanganate solution for $30 \mathrm{~min}$ before rinsing three times with sterile deionized water prior to sowing.

Table 1. Soil chemical properties of the three different unsterilized and sterilized soils used in the glasshouse experiment (mean $\pm 1 \mathrm{SE}, \mathrm{n}=5$ ).

\begin{tabular}{|c|c|c|c|c|c|c|}
\hline \multirow{2}{*}{$\begin{array}{c}\text { Soil } \\
\text { Properties }\end{array}$} & \multicolumn{3}{|c|}{ Unsterilized Soil } & \multicolumn{3}{|c|}{ Sterilized Soil } \\
\hline & RS & HS & PS & RS & HS & PS \\
\hline $\operatorname{SOC}\left(\mathrm{g} \mathrm{kg}^{-1}\right)$ & $38.30 \pm 0.19 a$ & $25.67 \pm 0.60 c$ & $35.23 \pm 0.05 b$ & $37.94 \pm 0.34 \mathrm{a}$ & $24.38 \pm 0.22 c$ & $34.95 \pm 0.06 b$ \\
\hline $\mathrm{TN}\left(\mathrm{g} \mathrm{kg}^{-1}\right)$ & $3.70 \pm 0.04 \mathrm{a}$ & $2.80 \pm 0.05 b$ & $2.59 \pm 0.06 b$ & $3.76 \pm 0.02 \mathrm{a}$ & $2.83 \pm 0.05 b$ & $2.62 \pm 0.03 c$ \\
\hline $\mathrm{TP}\left(\mathrm{g} \mathrm{kg}^{-1}\right)$ & $1.018 \pm 0.006 \mathrm{aA}$ & $0.660 \pm 0.007 b$ & $0.650 \pm 0.005 \mathrm{bA}$ & $0.988 \pm 0.007 \mathrm{aB}$ & $0.676 \pm 0.007 b$ & $0.668 \pm 0.004 \mathrm{bB}$ \\
\hline $\mathrm{SAP}\left(\mathrm{mg} \mathrm{kg}^{-1}\right)$ & $14.35 \pm 0.14 \mathrm{aA}$ & $5.23 \pm 0.14 \mathrm{bA}$ & $3.02 \pm 0.05 \mathrm{cA}$ & $15.34 \pm 0.41 \mathrm{aB}$ & $5.66 \pm 0.06 \mathrm{bB}$ & $3.41 \pm 0.09 \mathrm{cB}$ \\
\hline
\end{tabular}

RS, R. nepalensis soil; HS, H. rhamnoides soil; PS, P. asperata soil; SOC, soil organic carbon; TN, soil total nitrogen $\mathrm{TP}$, soil total phosphorus; SAP, soil available phosphorus. Different lowercase letters in the same row indicate statistically significant differences among the three different soils in the same treatment $(p<0.05)$. Different uppercase letters in the same row indicate statistically significant differences between unsterilized and sterilized soils of the same type $(p<0.05)$.

The pot culture experiment was established in the following treatment combinations: three soil origins (herb, shrub, tree) $\times$ two soil treatments (sterile, nonsterile). Each treatment combination was replicated ten times, resulting in a total of 60 individual pots (11 cm high, $12 \mathrm{~cm}$ in diameter). All soil-collection and potting equipment was cleaned and then sterilized with $75 \%(v / v)$ ethanol between soil treatment combinations to avoid cross-contamination. To ensure seedling establishment, the soil was well watered before sowing, and seeds of $R$. nepalensis were sown into holes in the soil. Weeds and grasses were manually removed from the pots to eliminate the potential effects of other plants. The pots were watered with deionized water every two days and weighed regularly in order to 
keep soil moisture content at the $40 \%-50 \%(w / w)$ level. The pots were arranged randomly on glasshouse benches and were rotated periodically to reduce the effects of potential variations in the glasshouse microclimate. The glasshouse conditions were maintained such that the air humidity was maintained from $75 \%-80 \%$. The daytime temperatures ranged from 20 to $24{ }^{\circ} \mathrm{C}$, and the nighttime temperatures ranged from 16 to $20{ }^{\circ} \mathrm{C}$. A constant photoperiod was applied throughout the experiment using supplemental growth lights to ensure $10 \mathrm{~h}$ of daylight, in accordance with the light period in the field. After a 4-month growth period, all seedlings of $R$. nepalensis were harvested.

\subsection{Photosynthesis and Chlorophyll Measurements}

Five pots were randomly selected from each soil treatment. Two leaves from the different plants in each pot were chosen and signed for the measurements. The open gas-exchange system (LI-6400XT, Li-Cor Inc., Lincoln, NE, USA) is used to measure the net photosynthetic rate (Pn) of the leaves between 08:30 and 11:30 in the morning. The saturating photon flux density was set at $800 \mu \mathrm{mol} \mathrm{m}^{-2} \mathrm{~s}^{-1}$. The conditions in the leaf chamber were similar to the growth conditions and maintained at $20-23{ }^{\circ} \mathrm{C}$, about $25 \%$ relative humidity and $380-400 \mu \mathrm{mol} \mathrm{mol}^{-1}$ ambient $\mathrm{CO}_{2}$ concentration. Before measurement, the leaves were placed in the leaf chamber for 5 minutes to gain photosynthetic stability. Measurements were made in triplicate from the two previously labeled leaves. At the end of the Pn measurements, the marked leaves were excised for determinations of $\mathrm{Chl} \mathrm{a}, \mathrm{Chl} b$ and $\mathrm{Chl} \mathrm{a}+\mathrm{b}$ in fresh leaves using the method described by Inskeep and Bloom [41].

\subsection{Plant and Soil Sampling}

All R. nepalensis plants were harvested and separated into their root and shoot parts. All plant samples were washed with tap water and dried at $80{ }^{\circ} \mathrm{C}$ to constant weights. The root to shoot biomass ratio (g root/g shoot plant) were calculated on the basis of the values from the measured plants. All rhizosphere soil samples were carefully collected by collecting all the soil adhering to the roots after gentle shaking; the samples were then homogenized and passed through a $1-\mathrm{mm}$-mesh sieve. Each soil sample was divided into three subsamples: one was stored at $-20^{\circ} \mathrm{C}$ for microbial biomass analysis and enzyme activity analysis, one was stored at $4{ }^{\circ} \mathrm{C}$ for available nutrient analysis, and one was air-dried and sieved using a $0.25 \mathrm{~mm}$ mesh for other chemical analysis.

\subsection{Soil Property Analysis}

The soil organic carbon (SOC) concentration was determined using $\mathrm{H}_{2} \mathrm{SO}_{4}-\mathrm{K}_{2} \mathrm{Cr}_{2} \mathrm{O}_{7}$ oxidation, and the soil total nitrogen (TN) concentration was measured with a $\mathrm{C} / \mathrm{N}$ elemental analyzer (Multi-N/C 2100, Analytik Jena AG, Jena, Germany). The soil total phosphorus (TP) concentration was measured using an inductively coupled plasma-atomic emission spectrometer (ICP-AES Optima 8300, PerkinElmer, Waltham, American) after digestion with $\mathrm{H}_{2} \mathrm{SO}_{4}$ and $\mathrm{HClO}_{4}$ solution [42], and soil available phosphorus (SAP) was extracted with Bray-I solution [43] and then measured using the same ICP-AES method used for TP determination. Soil ammonium nitrogen (AN) and nitrate nitrogen (NN) were extracted by $2 \mathrm{M} \mathrm{KCl}$ (soil: solution = 1:5) and then determined on a continuous flow injection analyzer (SEAL Analytical, Norderstedt, Germany). Soil total soluble nitrogen (TSN) was measured using the same apparatus used for AN measurement. The concentrations of soil microbial biomass carbon, nitrogen and phosphorus (SMBC, SMBN and SMBP) were determined by the chloroform fumigation method [44]. The potential activities of the primary soil organic carbon-, nitrogen- and phosphorus-degrading enzymes ( $\beta$-1,4-glucosidase (BG), $\beta$-N-acetylglucosaminidase (NAG), and acid phosphatase (AP)) were determined using a fluorometric microplate assay with a 4-methylumbelliferylsubstrate conjugate [45]. Soil pH was measured with a pH electrode (FE28-Meter, Mettler Toledo, Zurich, Switzerland) in a suspension with a 1:2.5 (w:v) ratio of soil to deionized water. 


\subsection{Statistical Analysis}

One-way analysis of variance (ANOVA) with the least significant difference (LSD) test (significant at the $p<0.05$ level) for post hoc multiple comparisons was applied to examine the effects of three different soils on Pn, chlorophyll concentrations, biomass and biomass allocation in $R$. nepalensis. Independent-samples $t$-test was used to compare the mean values of the plant traits in unsterilized soil vs. sterilized soil. If the data were heterogeneous, they were transformed to meet the assumptions necessary for ANOVA prior to the analysis. To test whether the soil microbes and nutrient properties influenced the chlorophyll concentrations, Pn, biomass or biomass allocation of $R$. nepalensis, redundancy analysis (RDA) was carried out with CANOCO 5.0 (Biometris, Wageningen, The Netherlands). We constructed a structural equation model (SEM) using AMOS 22 (SPSS Inc., Chicago, IL, USA) to examine how soil properties affect the performance of $R$. nepalensis in unsterilized soils. The following indices were used to verify whether our data conformed to the model: Chi-square/ df (Normed chi-square, $\mathrm{NC}$ ) $<2, p$ values $>0.05$; goodness of fit index $(\mathrm{GFI})>0.90$ and root mean square error of approximation (RMSEA) $<0.05$ [46]. The basic analyses above were performed and the graphics were created mainly in the 'vegan' and 'ggplot2' packages in R4.0.0 [47].

\section{Results}

\subsection{Soil Properties}

Initially, the SOC, TN and TP of the unsterilized soils from the different rooting zones were roughly similar to those of the sterilized soils; only SAP increased slightly after sterilization (Table 1). At the end of the experiment, the SOC, TN, TDN, NN, AN and SAP were significantly lower in sterilized soils than in unsterilized soils (Table 2), especially for the available $\mathrm{N}$ levels (i.e., TSN, NN and AN). In unsterilized soils, SMBC and NAG activity were the highest in the PS treatment and the lowest in the RS treatment.

Table 2. Soil properties of the three different unsterilized and sterilized soils after 4 months of $R$. nepalensis growth (mean $\pm 1 \mathrm{SE}, \mathrm{n}=5$ ).

\begin{tabular}{|c|c|c|c|c|c|c|}
\hline \multirow{2}{*}{ Soil Properties } & \multicolumn{3}{|c|}{ Unsterilized Soil } & \multicolumn{3}{|c|}{ Sterilized Soil } \\
\hline & RS & HS & PS & RS & HS & PS \\
\hline $\mathrm{SOC}\left(\mathrm{g} \mathrm{kg}^{-1}\right)$ & $39.13 \pm 0.45 \mathrm{aA}$ & $26.8 \pm 0.21 \mathrm{cA}$ & $35.4 \pm 0.02 \mathrm{bA}$ & $36.94 \pm 0.17 \mathrm{aB}$ & $24.09 \pm 0.07 \mathrm{cB}$ & $31.96 \pm 0.39 \mathrm{bB}$ \\
\hline $\mathrm{TN}\left(\mathrm{g} \mathrm{kg}^{-1}\right)$ & $3.96 \pm 0.04 \mathrm{aA}$ & $3.01 \pm 0.02 \mathrm{bA}$ & $3.11 \pm 0.03 \mathrm{~b} \mathrm{~A}$ & $3.81 \pm 0.04 \mathrm{aB}$ & $2.94 \pm 0.03 \mathrm{bB}$ & $2.72 \pm 0.02 \mathrm{cB}$ \\
\hline $\mathrm{TP}\left(\mathrm{g} \mathrm{kg}^{-1}\right)$ & $0.840 \pm 0.007 \mathrm{a}$ & $0.530 \pm 0.004 \mathrm{cA}$ & $0.556 \pm 0.005 \mathrm{bA}$ & $0.814 \pm 0.013 \mathrm{a}$ & $0.572 \pm 0.011 \mathrm{bB}$ & $0.518 \pm 0.004 \mathrm{cB}$ \\
\hline DTN (mg kg $\left.{ }^{-1}\right)$ & $17.23 \pm 0.36 \mathrm{bA}$ & $10.32 \pm 0.33 \mathrm{cA}$ & $21.14 \pm 0.69 \mathrm{aA}$ & $10.65 \pm 0.44 \mathrm{aB}$ & $6.10 \pm 0.13 \mathrm{bB}$ & $6.44 \pm 0.23 \mathrm{bB}$ \\
\hline $\mathrm{NN}\left(\mathrm{mg} \mathrm{kg}^{-1}\right)$ & $10.55 \pm 0.48 \mathrm{bA}$ & $7.74 \pm 0.48 \mathrm{cA}$ & $15.94 \pm 1.13 \mathrm{aA}$ & $2.74 \pm 0.27 \mathrm{aB}$ & $1.50 \pm 0.16 \mathrm{bB}$ & $2.26 \pm 0.20 \mathrm{aB}$ \\
\hline $\mathrm{AN}\left(\mathrm{mg} \mathrm{kg}^{-1}\right)$ & $3.32 \pm 0.14 \mathrm{bA}$ & $2.65 \pm 0.06 \mathrm{cA}$ & $4.25 \pm 0.11 \mathrm{aA}$ & $1.82 \pm 0.11 \mathrm{aB}$ & $1.47 \pm 0.02 \mathrm{bB}$ & $1.48 \pm 0.04 \mathrm{bB}$ \\
\hline $\operatorname{SAP}\left(\mathrm{mg} \mathrm{kg}^{-1}\right)$ & $10.03 \pm 0.26 \mathrm{aA}$ & $5.06 \pm 0.07 \mathrm{bA}$ & $2.63 \pm 0.07 \mathrm{cA}$ & $9.06 \pm 0.15 \mathrm{aB}$ & $3.59 \pm 0.04 \mathrm{bB}$ & $1.79 \pm 0.09 \mathrm{cB}$ \\
\hline $\mathrm{SMBC}\left(\mathrm{mg} \mathrm{kg}^{-1}\right)$ & $230.71 \pm 10.30 \mathrm{c}$ & $303.18 \pm 11.05 b$ & $423.16 \pm 8.79 \mathrm{a}$ & ND & ND & ND \\
\hline SMBN (mg kg $\left.{ }^{-1}\right)$ & $53.92 \pm 2.95 \mathrm{~b}$ & $72.31 \pm 3.08 \mathrm{a}$ & $80.51 \pm 3.92 \mathrm{a}$ & ND & ND & ND \\
\hline SMBP $\left(\mathrm{mg} \mathrm{kg}^{-1}\right)$ & $24.68 \pm 0.51 \mathrm{a}$ & $9.23 \pm 0.43 c$ & $13.19 \pm 0.86 b$ & ND & ND & ND \\
\hline $\mathrm{BG}\left(\mathrm{nmol} \mathrm{h}^{-1} \mathrm{~g}^{-1}\right)$ & $186.15 \pm 7.11 \mathrm{a}$ & $122.07 \pm 6.33 b$ & $199.80 \pm 4.95 \mathrm{a}$ & ND & ND & ND \\
\hline $\operatorname{NAG}\left(\mathrm{nmol} \mathrm{h}^{-1} \mathrm{~g}^{-1}\right)$ & $37.79 \pm 2.80 c$ & $66.87 \pm 3.87 b$ & $255.20 \pm 4.82 \mathrm{a}$ & ND & ND & ND \\
\hline $\mathrm{AP}\left(\mathrm{nmol} \mathrm{h}^{-1} \mathrm{~g}^{-1}\right)$ & $151.75 \pm 6.27 \mathrm{a}$ & $97.55 \pm 2.95 c$ & $124.96 \pm 3.58 b$ & ND & ND & ND \\
\hline
\end{tabular}

RS, R. nepalensis soil; HS, H. rhamnoides soil; PS, P. asperata soil; SOC, soil organic carbon; TN, soil total nitrogen $\mathrm{TP}$, soil total phosphorus; SAP, soil available phosphorus; TSN, soil total soluble nitrogen; NN, soil nitrate nitrogen; AN, soil ammonium nitrogen; BG, $\beta$-1,4-glucosidase; NAG, $\beta-1,4-\mathrm{N}$-acetylglucosaminidase; $\mathrm{AP}$, acid phosphatase; SMBC, soil microbial biomass carbon; SMBN, soil microbial biomass nitrogen; SMBP, soil microbial biomass phosphorus; ND, no data/not measured. Different lowercase letters in the same row indicate statistically significant differences among three different soils in the same treatment $(p<0.05)$. Different uppercase letters in the same row indicate statistically significant differences between unsterilized and sterilized soils of the same type $(p<0.05)$.

\subsection{Biomass and Biomass Allocation}

The root, shoot, and total biomasses of $R$. nepalensis in the different unsterilized soils followed the order of RS > HS > PS, respectively, while in the sterilized soils, they were ranked as RS > PS > HS (Figure $1 \mathrm{a}-\mathrm{c}$ ). The total biomass of $R$. nepalensis in the unsterilized 
RS was approximately 19.8 times that in the unsterilized PS and 16.5 times higher in the sterilized PS than in the unsterilized PS $(p<0.001)$ (Figure 1c). The root to shoot biomass ratio were the highest in the sterilized PS and the lowest in the unsterilized PS, and showed a significant response to the soil sterilization treatment in RS and PS ( $p<0.05$, Figure 1d).
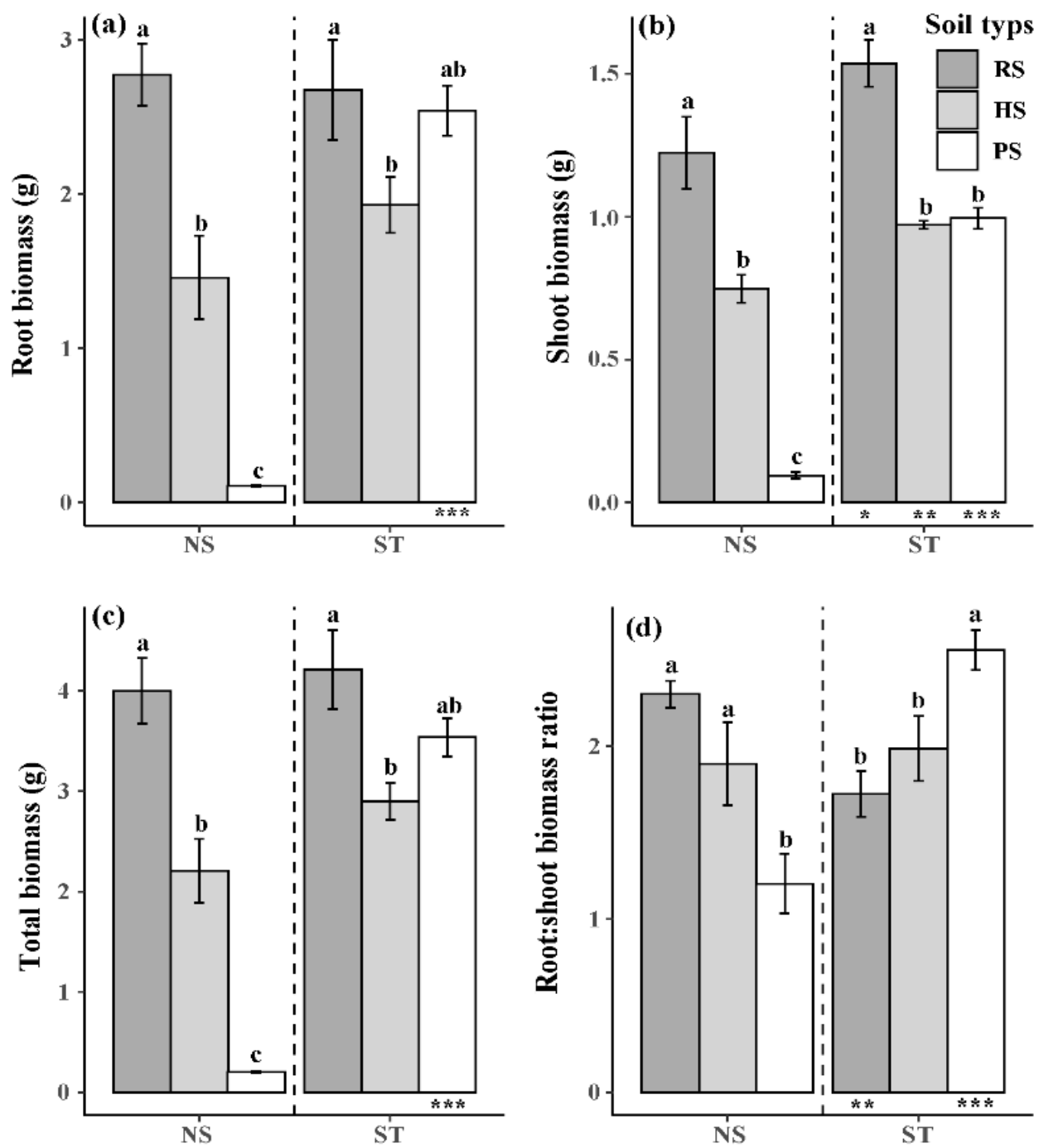

Figure 1. Effects of different soils on plant biomass and biomass allocation in R. nepalensis. (a) root biomass; (b) shoot biomass; (c) total biomass; (d) root to shoot biomass. Bars show the mean values; error bars represent \pm SEs $(n=5)$. Different letters above the error bars indicate significant differences $(p<0.05)$ among the various soil types (RS, R. nepalensis soil; HS, H. rhamnoides soil; PS, P. asperata soil). Asterisks under the bars represent significant differences in plant growth in nonsterile (NS) versus sterile (ST) soil according to a $t$-test $\left({ }^{*}, 0.01<p<0.05 ;{ }^{* *}, p<0.01 ;{ }^{* * *}, p<0.001\right)$.

\subsection{Photosynthesis and Chlorophyll}

In the unsterilized soils, the $\mathrm{Chl} \mathrm{a}, \mathrm{Chl} \mathrm{a}+\mathrm{b}$ and Pn of $\mathrm{R}$. nepalensis differed significantly among the three different soils $(p<0.05)$, ranking RS > HS > PS (Figure $2 \mathrm{a}-\mathrm{c}$ ). Chl b was significantly higher in RS and HS than in PS (Figure 2b). In the sterilized soils, the Chl a, $\mathrm{Chl} \mathrm{b}$ and $\mathrm{Chl} \mathrm{a}+\mathrm{b}$ were the highest in RS $(p<0.05)$ and were significantly higher than those in HS and PS (Figure 2a-c). The Chl a, Chl a $+\mathrm{b}$ and Pn of R. nepalensis in PS were remarkably enhanced by soil sterilization treatment $(p<0.001$, Figure $2 a-d)$. 

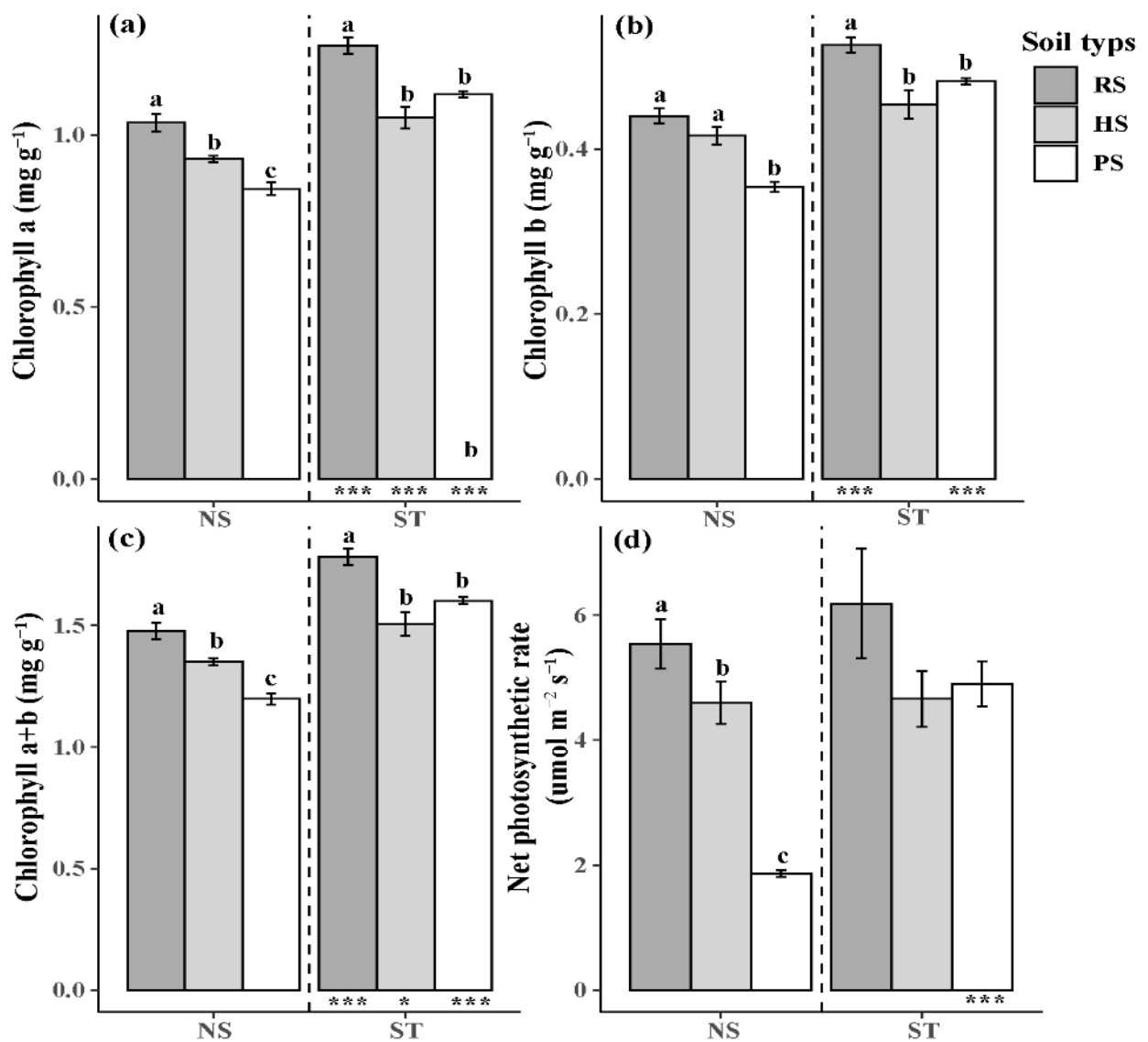

Figure 2. Effects of different soils on plant chlorophylls in fresh leaves and net photosynthetic rate of $R$. nepalensis. (a) Chlorophyll a; (b) Chlorophyll b; (c) Chlorophyll a + b; (d) Net photosynthetic rate. Bars show the mean values; error bars represent \pm SEs $(n=5)$. Different letters above the error bars indicate significant differences $(p<0.05)$ among the various soil types. Asterisks under the bars represent significant differences in plant growth in nonsterile (NS) versus sterile (ST) soil according to a $t$-test $\left({ }^{*}, 0.01<p<0.05 ;{ }^{* * *}, p<0.001\right)$.

\subsection{Effects of Soil Factors on Plant Performance}

The constrained RDA indicated that the constraining variables accounted for $97.5 \%$ and $47.0 \%$ of the total variances in the unsterilized and sterilized soils, respectively. In the unsterilized soils, NAG activity and SMBC were two main soil factors affecting plant performance, accounting for $79.9 \%$ and $79.0 \%$ of the total variance (simple effect, $p=0.002$ ), respectively (Figure 3a). However, the TSN concentration was the most significant variable affecting plant performance, accounting for $31.2 \%$ of the total variance in the sterilized soils (Figure $3 b$ ).

The model based on all indicators fully fitted the data describing the impacts of soil properties on plant performance $\left(\chi^{2}=2.610, p=0.625\right.$, NC $=0.652$, RMSEA $<0.001$, GFI $=0.941$; Figure 4$)$ in the unsterilized soils, which accounted for $85 \%$ of the variation in shoot biomass and $78 \%$ of the variation in root biomass and showed that SMBC could directly influence the root biomass and indirectly impact the Pn and shoot biomass via soil NAG activity. 

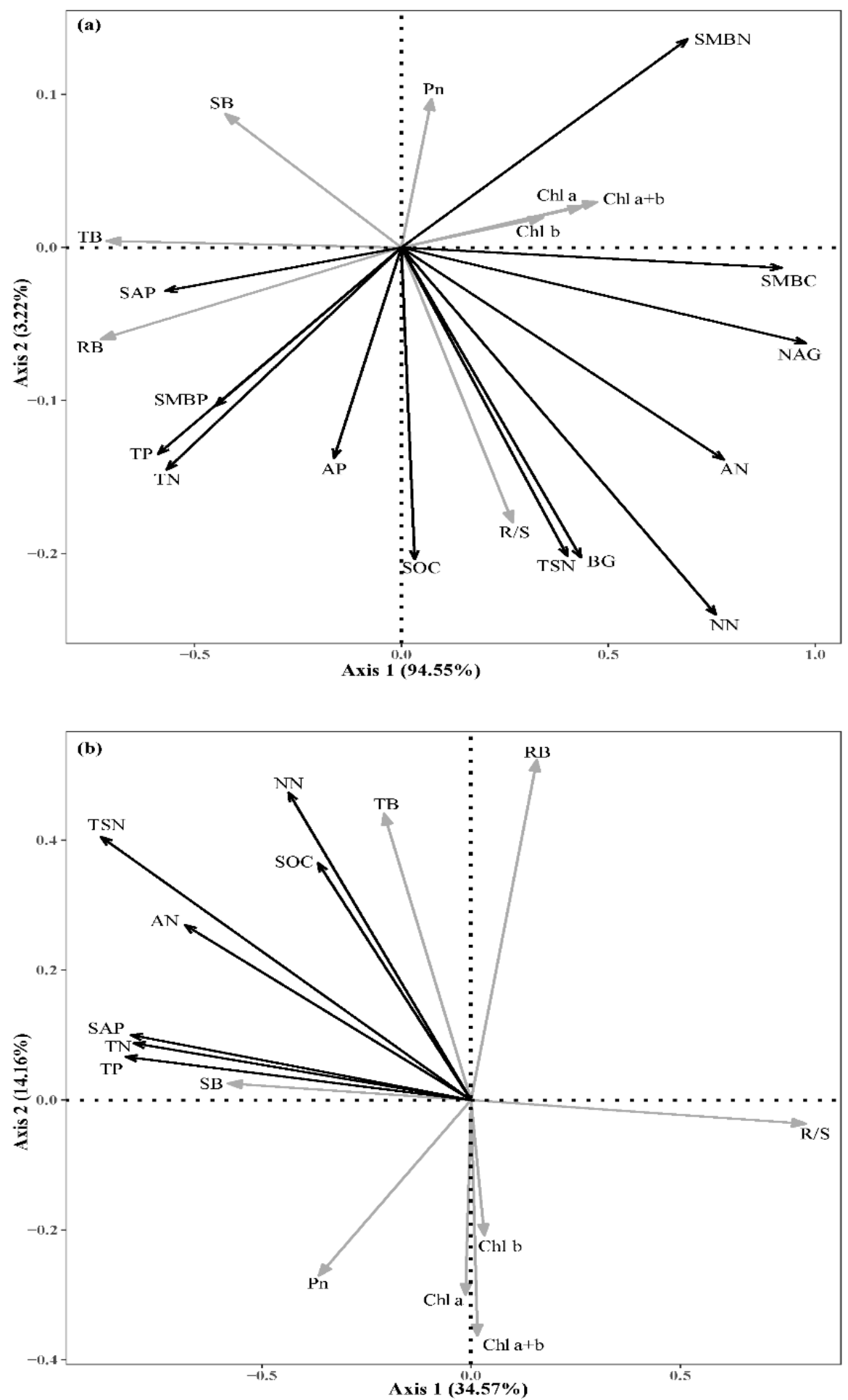

Figure 3. Bidimensional graph of the redundancy analysis, indicating the relationships between plant growth indexes and soil parameters, in the unsterilized soils (a) and sterilized soils (b). SB, shoot biomass; RB, root biomass; TB, total biomass; R/S, root to shoot biomass; Pn, net photosynthetic rate; Chl a, chlorophyll a; Chl b, chlorophyll b; Chl a + b, chlorophyll a + b; SOC, soil organic carbon; TN, soil total nitrogen; TP, soil total phosphorus; SAP, soil available phosphorus; TSN, soil total soluble nitrogen; $\mathrm{NN}$, soil nitrate nitrogen; $\mathrm{AN}$, soil ammonium nitrogen; $\mathrm{BG}, \beta-1,4$-glucosidase; NAG, $\beta$-1,4-N-acetylglucosaminidase; AP, acid phosphatase; SMBC, soil microbial biomass carbon; $\mathrm{SMBN}$, soil microbial biomass nitrogen; SMBP, soil microbial biomass phosphorus. 


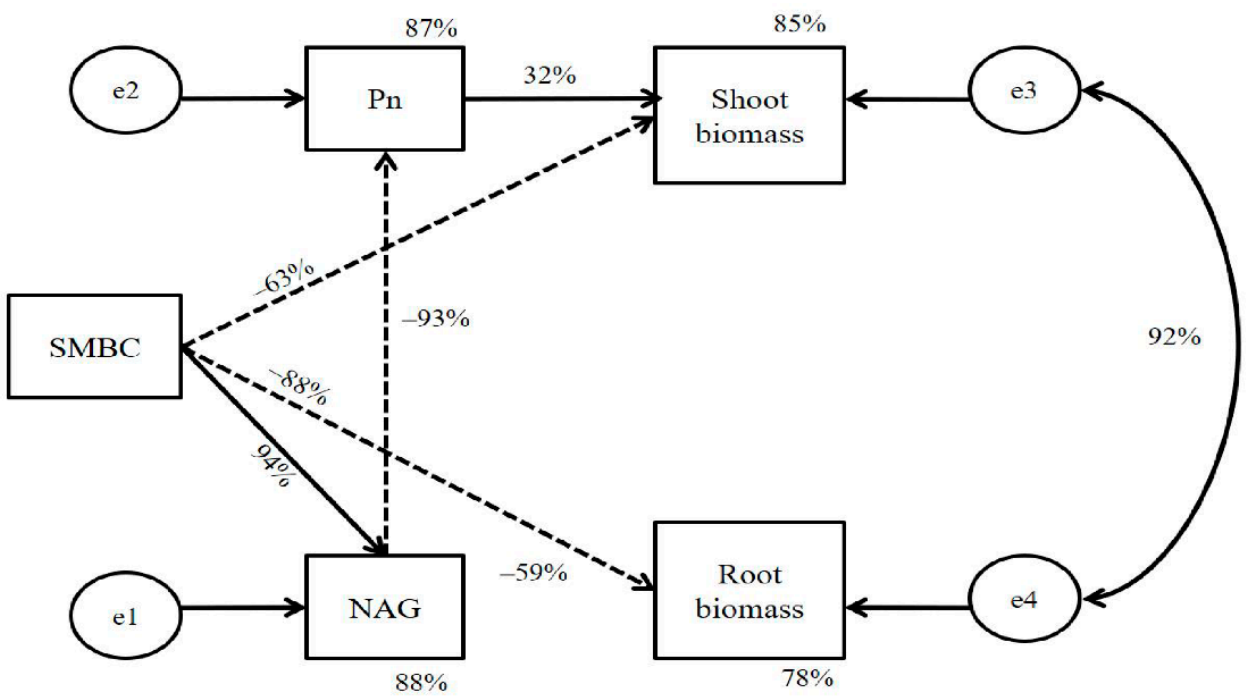

Figure 4. Results of the structural equation models of the effects of SMBC and soil NAG activity on plant Pn and biomass in the unsterilized soils. The model fit the data well: Chi-square $=2.610, \mathrm{df}=4$, $p=0.625, \mathrm{NC}=0.652$, RMSEA $<0.001$, GFI $=0.941$. The numbers on the arrows are the standardized path coefficients (equivalent to correlation coefficients). Circles indicate the error terms (e1-e4). Percentages close to endogenous variables indicate the percentage of the variance explained by that variable in the model. Solid and dashed lines represent positive and negative effects, respectively.

\section{Discussion}

In this study, we conducted a pot experiment to investigate the effects of soils from the rooting zones of three different plants on the performance of $R$. nepalensis. First, the effects of the soil microbes on $R$. nepalensis performance differed among the soil types, with the inhibition gradually increasing from grassland, shrubland to forest. Second, soil TSN was the significant soil factor influencing $R$. nepalensis biomass in the sterilized soils, and SMBC and NAG were the most important soil factors influencing plant growth in the unsterilized soils. Therefore, our results indicated that soil microbes and TSN could strongly influence $R$. nepalensis performance, which may provide insights into the different performance of R. nepalensis across grasslands, shrublands and forests.

\subsection{Feedback Effects of Different Soils on Plant Biomass and Physiology}

Among the unsterilized soils, the photosynthesis indices, and biomass of $R$. nepalensis were the highest in RS and the lowest in PS. These results are consistent with our first hypothesis that the different soils would differentially affect $R$. nepalensis photosynthesis, biomass and biomass allocation. The overall inhibitory effect of various soils on $R$. nepalensis performance would significantly become enhanced with the increase in soil microbial biomass from grassland, shrubland to forest [25]. The total biomass of R. nepalensis increased to some extent after soil sterilization; most notably, in PS. Therefore, our results could indicate that the inhibitory effect of soil microbes was removed after soil sterilization [48,49]. In the unsterilized PS, SMBC was the highest, but the biomass of $R$. nepalensis was the lowest. This response was probably due to the existence of large amount of harmful soil organisms (especially for the soil pathogens and root herbivores) in live PS [25,49], which may partially explain the fact that $R$. nepalensis does not grow in the understory of natural mature P. asperata forests.

Biomass allocation refers to the distribution of dry matter accumulated within a period of time to each plant part and is usually influenced by the growth environment, evolutionary history and interplant competition; these factors may directly affect the ability of plants to adapt to the environment [40-52]. The root: shoot (below: above ground) biomass ratio $(R / S)$ is generally used to characterize changes of photosynthetic product distribution pattern and could most directly reflect biomass allocation by plants [53,54]. 
The R/S was the lowest in the unsterilized PS and the highest in the sterilized PS, which indicated that soil microbes in PS might have a significant inhibiting effect on root growth of $R$. nepalensis. There are several possible explanations for this. First, large amounts of root herbivores (e.g., root-feeding nematodes) may exist in the unsterilized PS and damage more plant roots, thereby dramatically reducing the R/S of $R$. nepalensis [55-57]. Secondly, $R$. nepalensis plant may tend to form weak associations with soil mutualists and be more susceptible to pathogens in the unsterilized PS [48,58]. Overall, the R/S of R. nepalensis showed different responses to the soil treatments, supporting our hypothesis that different soils make plant biomass allocation strategies diverse.

Photosynthesis is a most important metabolic process of plants, which is a sensitive indicator in reflecting changes of external environment [53]. Chlorophylls, including Chl $\mathrm{a}, \mathrm{Chl} \mathrm{b}$ and $\mathrm{Chl} \mathrm{a}+\mathrm{b}$, are vital indicators of plant photosynthesis and can indicate the ability of plants to convert photosynthetic energy into biomass [59]. Differences in Pn and chlorophyll levels are often used to measure plant responses to different environmental conditions and plant stress resistance mechanisms [60]. In the unsterilized soils, Chl a, $\mathrm{Chl} \mathrm{b}, \mathrm{Chl} \mathrm{a}+\mathrm{b}$ and Pn in R. nepalensis differed markedly among the three different soils and were the lowest in PS. These results suggest that R. nepalensis growth would be greatly suppressed in the understory of natural mature P. asperata forests in these soil environments, consistent with our second hypothesis. Moreover, these indices related to plant photosynthesis had higher values in the sterilized soils than in the unsterilized soils, suggesting that the soil microbe could affect the photosynthesis capability of $R$. nepalensis, and corresponding plant productivity [61,62].

\subsection{Important Soil Parameters Affecting Plant Performance}

In the sterilized soils, differences were observed in the performance of $R$. nepalensis in various soils with distinct soil nutrient contents. The constrained RDA indicated that TSN concentration was a significant soil nutrient index influencing the biomass of $R$. nepalensis in the sterilized soils. The nitrogen is one of the basic elements of metabolism in nature. Plants allocate more nitrogen to leaves in order to synthesize more chlorophyll to increase plant photosynthesis and achieve faster growth, and even small changes in nitrogen allocations would immensely affect Pn and thereby plant growth $[63,64]$. In addition, the nitrogen was usually considered a major limiting element for plant growth in subalpine terrestrial ecosystems of southwestern China $[65,66]$. It is absorbed by plants as dissolved nitrogen in soil, including as dissolved organic nitrogen and dissolved inorganic nitrogen [67-69]. Therefore, soil TSN concentration was an extremely important soil parameter influencing the performance of $R$. nepalensis in the sterilized soils.

Both constrained RDA and path analysis suggested that SMNC and NAG activity were the main soil factors affecting the performance of $R$. nepalensis in the unsterilized soils, and the path analysis indicated that soil microbes could not only directly affect the root and shoot biomass but could also indirectly impact the photosynthesis and shoot biomass via the activities of extracellular enzymes (e.g., NAG). Soil extracellular enzymes are released mainly by soil microbes and participate in soil nutrient cycling [22,70]; for example, NAG degrades chitin and other $\beta-1,4$ glucosamine polymers as part of the nitrogen cycle [71] Soil microbes are superior competitors for organic and inorganic nitrogen in some natural contexts compared with plant roots because of their high surface area:volume ratios and rapid growth rates [72-74]. The SMBC level was the highest in the unsterilized PS, which suggested that competition between plants and soil microbes for nitrogen was more intense in this soil than in the other soils [21] and that the unsterilized PS might contain more microbes that inhibit the growth of $R$. nepalensis. Therefore, soil microbes may directly affect the performance of $R$. nepalensis via some soil pathogens and root herbivores; furthermore, soil microbes could compete for nitrogen via NAG activity and reduced the absorption of nitrogen by plants, thereby affecting the photosynthesis and growth of $R$. nepalensis. 


\section{Conclusions}

In conclusion, our results show that the growth of $R$. nepalensis was inhibited by soil microbes from the rooting zone soils of different plants, especially in the live PS. Soil TSN content was the significant soil nutrient factor influencing the performance of R. nepalensis in the sterilized soils, and SMBC and NAG were the most important soil factors influencing $R$. nepalensis growth in the unsterilized soils. These results suggest that appropriate soil sterilization and nitrogen fertilizer application would benefit the establishment of $R$. nepalensis populations. Therefore, the feedback effects of different soil microbes on plant performance should be considered during $R$. nepalensis population development. Further studies exploring the different functional groups of soil microbes and the causal mechanisms regulating plant-soil microbe interactions are needed.

Author Contributions: H.H.: conceptualization, data curation, formal analysis, investigation, methodology, project administration, resources, software, validation, visualization, writing-original draft, writing-review and editing. L.Y.: data curation, formal analysis, investigation, validation, visualization, writing-original draft. X.Y.: investigation, writing-review and editing. L.L.: formal analysis, visualization. J.L.: resources, writing-review and editing. J.C.: investigation. Y.K.: methodology. W.Z. and Q.L.: conceptualization, funding acquisition, methodology, project administration, supervision, writing-original draft, writing-review and editing. All authors have read and agreed to the published version of the manuscript.

Funding: This study was funded by the National Natural Science Foundation of China (41930645, 31971637, 31870607), Youth Innovation Promotion Association of the Chinese Academy of Sciences (2019363), National Key Research and Development Program of China (2017YFC0505000), and the Science and Technology Basic Work Project of China (2015FY110300).

Institutional Review Board Statement: Not applicable.

Informed Consent Statement: Not applicable.

Data Availability Statement: Dataset and associated codes used in the main results are available upon reasonable request to the corresponding author.

Acknowledgments: We would like to thank Ting Liang, Xiaohu Wang and Xiaoying Zhang for experimental assistance. We also thank the staff of the Maoxian Mountain Ecosystem of CERN Research Station for providing regional meteorological monitoring data.

Conflicts of Interest: The authors declare no conflict of interest.

\section{References}

1. Bever, J.D. Soil community feedback and the coexistence of competitors: Conceptual frameworks and empirical tests. New Phytol. 2003, 157, 465-473. [CrossRef] [PubMed]

2. $\quad$ van der Putten, W.H.; Bardgett, R.D.; Bever, J.D.; Bezemer, T.M.; Casper, B.B.; Fukami, T.; Kardol, P.; Klironomos, J.N.; Kulmatiski, A.; Schweitzer, J.A.; et al. Plant-soil feedbacks: The past, the present and future challenges. J. Ecol. 2013, 101, 265-276. [CrossRef]

3. Yan, Y.; Dai, Q.; Hu, G.; Jiao, Q.; Mei, L.; Fu, W. Effects of vegetation type on the microbial characteristics of the fissure soil-plant systems in karst rocky desertification regions of SW China. Sci. Total Environ. 2020, 712, 136543. [CrossRef]

4. Carteron, A.; Parasquive, V.; Blanchard, F.; Guilbeault-Mayers, X.; Turner, B.L.; Vellend, M.; Laliberte, E. Soil abiotic and biotic properties constrain the establishment of a dominant temperate tree into boreal forests. J. Ecol. 2020, 108, 931-944. [CrossRef]

5. Zhao, J.; Li, S.; He, X.; Liu, L.; Wang, K. The soil biota composition along a progressive succession of secondary vegetation in a karst area. PLoS ONE 2014, 9, 0112436. [CrossRef] [PubMed]

6. $\quad$ Rodrigues, P.M.S.; Schaefer, C.E.G.A.R.; Silva, J.D.O.; Ferreira Junior, W.G.; Dos Santos, R.M.; Neri, A.V. The influence of soil on vegetation structure and plant diversity in different tropical savannic and forest habitats. J. Plant. Ecol. 2016, 11, 226-236. [CrossRef]

7. Kutakova, E.; Herben, T.; Munzbergova, Z. Heterospecific plant-soil feedback and its relationship to plant traits, species relatedness, and co-occurrence in natural communities. Oecologia 2018, 187, 679-688. [CrossRef]

8. Aschehoug, E.T.; Brooker, R.; Atwater, D.Z.; Maron, J.L.; Callaway, R.M. The mechanisms and consequences of interspecific competition among plants. Annu. Rev. Ecol. Evol. Syst. 2016, 47, 263-281. [CrossRef]

9. Callaway, R.M.; DeLucia, E.H.; Moore, D.; Nowak, R.; Schlesinger, W.H. Competition and facilitation: Contrasting effects of Artemisia tridentata on desert vs montane pines. Ecology 1996, 77, 2130-2141. [CrossRef] 
10. Balicka, A.; Szadkowska, D. XRF analysis of heavy metals contents in oak wood (Quercur robur L.). Ann. Warsaw Univ. Life Sci. SGGW For. Wood Technol. 2020, 109, 76-80. [CrossRef]

11. Niedbała, M. Selected techniques of soil contaminated phytoremediation with the use of hyperaccumulative plants and trees. Ann. Warsaw Univ. Life Sci.-SGGW For. Wood Technol. 2021, 115, 77-84. [CrossRef]

12. Zielenkiewicz, T.; Szadkowski, J.; Drożdżek, M.; Zielenkiewicz, A.; Kłosińska, T.; Antczak, A.; Zawadzki, J.; Gawron, J. Application of X-ray fluorescence technique for determination of heavy metals uptake by different species of poplar. Drewno 2016, 59, 113-126.

13. de la Pena, E.; Bonte, D. Soil biota effects on clonal growth and flowering in the forest herb Stachys sylvatica. Acta Oecol. 2011, 37, 110-116. [CrossRef]

14. Bennett, J.A.; Klironomos, J. Mechanisms of plant-soil feedback: Interactions among biotic and abiotic drivers. New Phytol. 2019, 222, 91-96. [CrossRef] [PubMed]

15. Smith-Ramesh, L.M.; Reynolds, H.L.; Michalet, R. The next frontier of plant-soil feedback research: Unraveling context dependence across biotic and abiotic gradients. J. Veg. Sci. 2017, 28, 484-494. [CrossRef]

16. Gross, N.; Kunstler, G.; Liancourt, P.; de Bello, F.; Suding, K.N.; Lavorel, S. Linking individual response to biotic interactions with community structure: A trait-based framework. Funct. Ecol. 2009, 23, 1167-1178. [CrossRef]

17. De Deyn, G.B.; Raaijmakers, C.E.; Van der Putten, W.H. Plant community development is affected by nutrients and soil biota. J. Ecol. 2004, 92, 824-834. [CrossRef]

18. Heinze, J.; Gensch, S.; Weber, E.; Joshi, J. Soil temperature modifies effects of soil biota on plant growth. J. Plant. Ecol. 2017, 10, 808-821. [CrossRef]

19. Bever, J.D.; Westover, K.M.; Antonovics, J. Incorporating the soil community into plant population dynamics: The utility of the feedback approach. J. Ecol. 1997, 85, 561-573. [CrossRef]

20. Kutakova, E.; Meszarosova, L.; Baldrian, P.; Munzbergova, Z. Evaluating the role of biotic and chemical components of plant-soil feedback of primary successional plants. Biol. Fert. Soils 2020, 56, 345-358. [CrossRef]

21. Kuzyakov, Y.; Xu, X.L. Competition between roots and microorganisms for nitrogen: Mechanisms and ecological relevance. New Phytol. 2013, 198, 656-669. [CrossRef] [PubMed]

22. Fatemi, F.R.; Fernandez, I.J.; Simon, K.S.; Dail, D.B. Nitrogen and phosphorus regulation of soil enzyme activities in acid forest soils. Soil Biol. Biochem. 2016, 98, 171-179. [CrossRef]

23. Raiesi, F.; Salek-Gilani, S. The potential activity of soil extracellular enzymes as an indicator for ecological restoration of rangeland soils after agricultural abandonment. Appl. Soil Ecol. 2018, 126, 140-147. [CrossRef]

24. Zhang, C.; Song, Z.L.; Zhuang, D.H.; Wang, J.; Xie, S.S.; Liu, G.B. Urea fertilization decreases soil bacterial diversity, but improves microbial biomass, respiration, and N-cycling potential in a semiarid grassland. Biol. Fert. Soils 2019, 55, 229-242. [CrossRef]

25. Castle, S.C.; Lekberg, Y.; Affleck, D.; Cleveland, C.C. Soil abiotic and biotic controls on plant performance during primary succession in a glacial landscape. J. Ecol. 2016, 104, 1555-1565. [CrossRef]

26. Shipley, B. Net assimilation rate, specific leaf area and leaf mass ratio: Which is most closely correlated with relative growth rate? A meta-analysis. Funct. Ecol. 2006, 20, 565-574. [CrossRef]

27. Sarker, U.; Oba, S. Drought stress enhances nutritional and bioactive compounds, phenolic acids and antioxidant capacity of Amaranthus leafy vegetable. BMC Plant Biol. 2018, 18, 258. [CrossRef]

28. Jahan, M.A.; Kovinich, N. Acidity stress for the systemic elicitation of glyceollin phytoalexins in soybean plants. Plant Signal Behav. 2019, 14, 1604018. [CrossRef]

29. Luo, X.F.; Dai, Y.J.; Zheng, C.; Yang, Y.Z.; Chen, W.; Wang, Q.C.; Chandrasekaran, U.; Du, J.; Liu, W.G.; Shu, K. The ABI4$\mathrm{RbohD/VTC2}$ regulatory module promotes reactive oxygen species (ROS) accumulation to decrease seed germination under salinity stress. New Phytol. 2021, 229, 950-962. [CrossRef]

30. Krause, G.H.; Weis, E. Chlorophyll fluorescence and photosynthesis: The basics. Annu. Rev. Plant Phys. 1991, 42, 313-349. [CrossRef]

31. Horn, R.; Grundmann, G.; Paulsen, H. Consecutive binding of chlorophylls a and b during the assembly in vitro of light-harvesting chlorophyll-a/b protein (LHCIIb). J. Mol. Biol. 2007, 366, 1045-1054. [CrossRef] [PubMed]

32. Verhoeven, K.J.F.; Biere, A.; Nevo, E.; Damme, J. Differential selection of growth rate-related traits in wild barley, Hordeum spontaneum, in contrasting greenhouse nutrient environments. J. Evol. Biol. 2004, 17, 184-196. [CrossRef]

33. Bresson, J.; Vasseur, F.; Dauzat, M.; Koch, G.; Granier, C.; Vile, D. Quantifying spatial heterogeneity of chlorophyll fluorescence during plant growth and in response to water stress. Plant Methods 2015, 11, 23. [CrossRef] [PubMed]

34. Duarte, C.M.; Losada, I.J.; Hendriks, I.E.; Mazarrasa, I.; Marbà, N. The role of coastal plant communities for climate change mitigation and adaptation. Nat. Clim. Chang. 2013, 3, 961-968. [CrossRef]

35. Abbaspour, H.; Saeidi-Sar, S.; Afshari, H.; Abdel-Wahhab, P.M. Tolerance of Mycorrhiza infected Pistachio (Pistacia vera L.) seedling to drought stress under glasshouse conditions. J. Plant Physiol. 2012, 169, 704-709. [CrossRef]

36. Kostenko, O.; Bezemer, T.M. Abiotic and biotic soil legacy effects of plant diversity on plant performance. Front. Ecol. Evol. 2020, 8, 87. [CrossRef]

37. Teste, F.P.; Kardol, P.; Turner, B.L.; Wardle, D.A.; Zemunik, G.; Renton, M.; Laliberte, E. Plant-soil feedback and the maintenance of diversity in Mediterranean-climate shrublands. Science 2017, 355, 173-176. [CrossRef] [PubMed] 
38. Zhang, Y.B.; Duan, B.L.; Xian, J.R.; Korpelainen, H.; Li, C.Y. Links between plant diversity, carbon stocks and environmental factors along a successional gradient in a subalpine coniferous forest in Southwest China. For. Ecol. Manag. 2011, 262, 361-369. [CrossRef]

39. Shaikh, S.; Shriram, V.; Srivastav, A.; Barve, P.; Kumar, V. A critical review on Nepal Dock (Rumex nepalensis): A tropical herb with immense medicinal importance. Asian Pac. J. Trop. Med. 2018, 11, 405-414.

40. Endlweber, K.; Scheu, S. Establishing arbuscular mycorrhiza-free soil: A comparison of six methods and their effects on nutrient mobilization. Appl. Soil Ecol. 2006, 34, 276-279. [CrossRef]

41. Inskeep, W.P.; Bloom, P.R. Extinction coefficients of chlorophyll a and b in N,N-dimethylformamide and $80 \%$ acetone. Plant Physiol. 1985, 77, 483-485. [CrossRef]

42. Bing, H.; Wu, Y.; Zhou, J.; Sun, H.; Luo, J.; Wang, J.; Yu, D. Stoichiometric variation of carbon, nitrogen, and phosphorus in soils and its implication for nutrient limitation in alpine ecosystem of Eastern Tibetan Plateau. J. Soils Sediments 2016, 16, 405-416. [CrossRef]

43. Bray, R.H.; Kurtz, L.T. Determination of total, organic, and available forms of phosphorus in soils. Soil Sci. 1945, 59, 39-46. [CrossRef]

44. Brookes, P.C.; Landman, A.; Pruden, G.; Jenkinson, D.S. Chloroform fumigation and the release of soil nitrogen: A rapid direct extraction method to measure microbial biomass nitrogen in soil. Soil Biol. Biochem. 1985, 17, 837-842. [CrossRef]

45. Saiya-Cork, K.R.; Sinsabaugh, R.L.; Zak, D.R. The effects of long term nitrogen deposition on extracellular enzyme activity in an Acer saccharum forest soil. Soil Biol. Biochem. 2002, 34, 1309-1315. [CrossRef]

46. Hooper, D.; Coughlan, J.; Mullen, M. Structural equation modelling: Guidelines for determining model fit. Electron J. Bus. Res. Methods 2008, 6, 53-60.

47. Team, R.C. R: A language and Enviroment for Stadistical Computing; R Foundation for Statistical Computing: Vienna, Austria, 2020.

48. van der Putten, W.H.; van Dijk, C.; Troelstra, S.R. Biotic soil factors affecting the growth and development of Ammophila arenaria. Oecologia 1988, 76, 313-320. [CrossRef] [PubMed]

49. Cardinaux, A.; Hart, S.P.; Alexander, J.M. Do soil biota influence the outcome of novel interactions between plant competitors? J. Ecol. 2018, 106, 1853-1863. [CrossRef] [PubMed]

50. Glynn, C.; Herms, D.A.; Egawa, M.; Hansen, R.; Mattson, W.J. Effects of nutrient availability on biomass allocation as well as constitutive and rapid induced herbivore resistance in poplar. Oikos 2003, 101, 385-397. [CrossRef]

51. Johnson, N.C.; Rowland, D.L.; Corkidi, L.; Allen, E.B. Plant winners and losers during grassland N-eutrophication differ in biomass allocation and mycorrhizas. Ecology 2008, 89, 2868-2878. [CrossRef] [PubMed]

52. Poorter, H.; Niklas, K.J.; Reich, P.B.; Oleksyn, J.; Poot, P.; Mommer, L. Biomass allocation to leaves, stems and roots: Meta-analyses of interspecific variation and environmental control. New Phytol. 2012, 193, 30-50. [CrossRef] [PubMed]

53. Ai, Z.M.; Zhang, J.Y.; Liu, H.F.; Xin, Q.; Xue, S.; Liu, G.B. Soil nutrients influence the photosynthesis and biomass in invasive Panicum virgatum on the Loess Plateau in China. Plant Soil 2017, 418, 153-164. [CrossRef]

54. Qi, Y.; Wei, W.; Chen, C.; Chen, L. Plant root-shoot biomass allocation over diverse biomes: A global synthesis. Glob. Ecol. Conserv. 2019, 18, 00606. [CrossRef]

55. Franco, A.L.C.; Gherardi, L.A.; de Tomasel, C.M.; Andriuzzi, W.S.; Ankrom, K.E.; Bach, E.M.; Guan, P.T.; Sala, O.E.; Wall, D.H. Root herbivory controls the effects of water availability on the partitioning between above- and below-ground grass biomass. Funct. Ecol. 2020, 34, 2403-2410. [CrossRef]

56. Erb, M.; Lu, J. Soil abiotic factors influence interactions between belowground herbivores and plant roots. J. Exp. Bot. 2013, 64, 1295-1303. [CrossRef]

57. Tsunoda, T.; Kachi, N.; Suzuki, J.-I. Effects of belowground vertical distribution of a herbivore on plant biomass and survival in Lolium perenne. Ecol. Res. 2014, 29, 351-355. [CrossRef]

58. Bever, J.D.; Mangan, S.A.; Alexander, H.M. Maintenance of Plant Species Diversity by Pathogens. Annu. Rev. Ecol. Evol. Syst. 2015, 46, 305-325. [CrossRef]

59. Mobin, M.; Khan, N.A. Photosynthetic activity, pigment composition and antioxidative response of two mustard (Brassica juncea) cultivars differing in photosynthetic capacity subjected to cadmium stress. J. Plant. Physiol. 2007, 164, 601-610. [CrossRef]

60. Bussotti, F.; Pollastrini, M.; Holland, V.; Bruggemann, W. Functional traits and adaptive capacity of European forests to climate change. Environ. Exp. Bot. 2015, 111, 91-113. [CrossRef]

61. Nowicka, B.; Ciura, J.; Szymanska, R.; Kruk, J. Improving photosynthesis, plant productivity and abiotic stress tolerance-Current trends and future perspectives. J. Plant Physiol. 2018, 231, 415-433. [CrossRef]

62. Malhi, Y.; Doughty, C.E.; Goldsmith, G.R.; Metcalfe, D.B.; Girardin, C.A.J.; Marthews, T.R.; del Aguila-Pasquel, J.; Aragao, L.E.O.C.; Araujo-Murakami, A.; Brando, P.; et al. The linkages between photosynthesis, productivity, growth and biomass in lowland Amazonian forests. Glob. Chang. Biol. 2015, 21, 2283-2295. [CrossRef]

63. Onoda, Y.; Hikosaka, K.; Hirose, T. Allocation of nitrogen to cell walls decreases photosynthetic nitrogen-use efficiency. Funct. Ecol. 2004, 18, 419-425. [CrossRef]

64. Shangguan, Z.P.; Shao, M.G.; Dyckmans, J. Effects of nitrogen nutrition and water deficit on net photosynthetic rate and chlorophyll fluorescence in winter wheat. J. Plant Physiol. 2000, 156, 46-51. [CrossRef]

65. Xu, Z.; Wan, C.; Xiong, P.; Tang, Z.; Hu, R.; Cao, G.; Liu, Q. Initial responses of soil $\mathrm{CO}_{2}$ efflux and C, N pools to experimental warming in two contrasting forest ecosystems, Eastern Tibetan Plateau, China. Plant Soil 2010, 336, 183-195. [CrossRef] 
66. Wang, Z.; Chen, Q.; Huang, Y.; Deng, H.; Shen, X.; Tang, S.; Zhang, J.; Liu, Y. Response of soil respiration and microbial biomass carbon and nitrogen to nitrogen application in subalpine forests of western Sichuan. Acta Ecol. Sin. 2019, 39, 7197-7207.

67. Nasholm, T.; Kielland, K.; Ganeteg, U. Uptake of organic nitrogen by plants. New Phytol. 2009, 182, 31-48. [CrossRef] [PubMed]

68. Persson, J.; Hogberg, P.; Ekblad, A.; Hogberg, M.N.; Nordgren, A.; Nasholm, T. Nitrogen acquisition from inorganic and organic sources by boreal forest plants in the field. Oecologia 2003, 137, 252-257. [CrossRef] [PubMed]

69. Miller, A.E.; Bowman, W.D.; Suding, K.N. Plant uptake of inorganic and organic nitrogen: Neighbor identity matters. Ecology 2007, 88, 1832-1840. [CrossRef]

70. Stark, S.; Mannisto, M.K.; Eskelinen, A. Nutrient availability and pH jointly constrain microbial extracellular enzyme activities in nutrient-poor tundra soils. Plant Soil 2014, 383, 373-385. [CrossRef]

71. Zhu, X.M.; Liu, M.; Kou, Y.P.; Liu, D.Y.; Liu, Q.; Zhang, Z.L.; Jiang, Z.; Yin, H.J. Differential effects of N addition on the stoichiometry of microbes and extracellular enzymes in the rhizosphere and bulk soils of an alpine shrubland. Plant Soil 2020, 449, 285-301. [CrossRef]

72. Kaye, J.P.; Hart, S.C. Competition for nitrogen between plants and soil microorganisms. Trends Ecol. Evol. 1997, 12, 139-143. [CrossRef]

73. Hodge, A.; Robinson, D.; Fitter, A. Are microorganisms more effective than plants at competing for nitrogen? Trends Plant Sci. 2000, 5, 304-308. [CrossRef]

74. Bardgett, R.D.; Streeter, T.C.; Bol, R. Soil microbes compete effectively with plants for organic-nitrogen inputs to temperate grasslands. Ecology 2003, 84, 1277-1287. [CrossRef] 